\title{
Parasite diversity of European Myotis species with special emphasis on Myotis myotis (Microchiroptera, Vespertilionidae) from a typical nursery roost
}

\author{
Raphael Frank', Thomas Kuhn ${ }^{1}$, Antje Werblow' ${ }^{1}$ Andrew Liston², Judith Kochmann ${ }^{1}$ and Sven Klimpel ${ }^{*}$
}

\begin{abstract}
Background: Bats belong to one of the most species-rich orders within the Mammalia. They show a worldwide distribution, a high degree of ecological diversification as well as a high diversity of associated parasites and pathogens. Despite their prominent and unique role, the knowledge of their parasite-host-relationships as well as the mechanisms of co-evolutionary processes are, partly due to strict conservation regulations, scarce.

Methods: Juvenile specimens of the greater mouse-eared bat (Myotis myotis) from a roosting colony in Gladenbach (Hesse, Germany) were examined for their metazoan endo-and ectoparasite infections and pathogens. Morphometric data were recorded and the individuals were checked for Lyssavirus-specific antigen using a direct immunofluorescence test. For unambiguous species identification, the bats were analysed by cyt-b sequence comparison.

Results: Myotis myotis were parasitized by the six insect and arachnid ectoparasite species, i.e. Ixodes ricinus, Ischnopsyllus octactenus, Ichoronyssus scutatus, Steatonyssus periblepharus, Spinturnix myoti and Cimex dissimilis. Additionally, the nematode Molinostrongylus alatus and the cestode Vampirolepis balsaci were recorded. Each bat was parasitized by at least four species. The parasites showed partially extreme rates of infection, never recorded before, with more than 1,440 parasites per single host. Ichoronyssus scutatus, Steatonyssus periblepharus, Vampirolepis balsaci and Molinostrongylus alatus are recorded for the first time in Germany. A checklist for Europe is presented containing records of 98 parasite species of 14 Myotis species.

Conclusions: The Myotis myotis from Gladenbach (Hesse, Germany) were parasitized by a diverse parasite fauna with high infestation rates. We assume that in juvenile Myotis the number of parasites is generally higher than in adults due to only later acquired immune competence and behavioural adaptations. Our results revealed new insights into parasite fauna of M. myotis and European bats in general. The finding of endoparasitic cyclophyllidean cestodes that have a two-host lifecycle is, considering the stationary behaviour of the juvenile bats, rather unusual and suggests a non-predatory transmission mechanism (e.g. via autoinfection).

A new insight gained from the collated literature was that the European wide composition of the Myotis parasite fauna is dominated by a few specific taxonomic groups in Europe.
\end{abstract}

Keywords: Myotis myotis, Spinturnix myoti, Ectoparasites, Roosting place

\footnotetext{
* Correspondence: klimpel@bio.uni-frankfurt.de

${ }^{1}$ Goethe-University (GU), Institute for Ecology, Evolution and Diversity;

Senckenberg Biodiversity and Climate Research Centre (SBiK-F), Senckenberg

Gesellschaft für Naturforschung (SGN), Max-von-Laue-Str. 13, Frankfurt am

Main D-60438, Germany

Full list of author information is available at the end of the article
} 


\section{Background}

As the second largest order worldwide within the Mammalia [1] bats show a high degree of ecological diversification. This variability is enabled by morphological, behavioural and physiological adaptations [2]. Paradoxically, one third of the indigenous mammalian species of Europe are bats of the suborder Microchiroptera, but details about the exact number of species or their distribution are still scarce [3]. The most diverse family is the Vespertilionidae, within which the genus Myotis comprises between 92 [4] and 100 species [5]. Most members of Myotis are distributed in the northern hemisphere [4] and at least 14 species are known in Europe. Based on genetic studies, speciation within the genus Myotis took place in geographically isolated populations [6]. As a result of habitat loss, several bat species populations increasingly use urbanised areas as alternative habitats [7]. The most common synanthropic species in Europe are Myotis daubentoni, M. dasycneme and M. myotis [8]. They live in close contact with humans and can act as vectors for several zoonotic pathogens. Several virus species, partly human pathogenic, are recorded in European bats such as coronaviruses (CoVs), filoviruses, henipaviruses and astroviruses (RNA viruses) as well as herpes-and adenoviruses (DNA viruses) [9]. The virus strains Lyssavirus genotype 5 and 6 (EBLV 1 and 2) (RNA-virus, Rhabdoviridae) are causing human rabies $[3,8,10]$. Long-term studies show that Eptesicus serotinus is the most common species in Germany with Lyssavirus infections [10], while only occasional reports of infection of $M$. myotis are known.

Beside the aforementioned virus diversity, M. myotis also shows a high diversity of metazoan endo-and ectoparasites. All bats in Germany are strictly protected, which severely limits opportunities for research on their parasite fauna and the number of studies in this field are comparatively low [11]. The few existing records of parasites in bats are from Eastern Europe, Austria, Switzerland, Great Britain and Spain (e.g. [12,13]) as well as Germany [14]. Because of its wide range of distribution, the parasite diversity research of $M$. myotis is of special interest in relation to the remaining 38 European bat species and is useful for other bat species to understand parasite- host ecology [10]. Another point is that ectoparasites may be capable of acting as vectors of the mentioned viruses as well as be human pathogenic. As for all other wild animals several ecological relationships are directly or indirectly linked to parasites. For instance, parasite induced avoidance strategies were observed in $M$. myotis [15]. In addition, physiological adaptations within the parasites were also postulated [16]. Beside strictly host specific parasites, several species occur on more than one Myotis species as well as members of other bat families [17]. Consequently, the potential parasite fauna of the European Myotis species is expected to be large; however, a comprehensive documentation of all known European Myotis species and associated parasites is missing.

The first aim of our study was to identify the parasite species of juvenile $M$. myotis from a Hessian (German) population. Our second aim was to provide a complete overview of the parasite fauna of European Myotis. For this, we compiled a parasite checklist that includes all new and previous metazoan parasite records of the 14 Myotis species in Europe.

\section{Methods}

\section{Sampling site and collection of parasites}

The study was carried out using 30 juvenile specimens of Myotis myotis (half males and females) which had died of natural causes. They were collected by a member of ChiroTEC [18] on July 21 in 2012 at the Martinskirche in Gladenbach, Hesse (Germany). The specimens were dead less than 48 hours. The nursery roost is located at the church's roof truss and was monitored by members of ChiroTEC. The coordinates of the sampling site are $\mathrm{N}$ 50.768213, E 8.583106. In 2011, the colony consisted of about 767 estimated adult females [19].

Sex and the following main morphometric data of each bat were recorded (Table 1): total weight, head-body length, forearm and upper arm length. In addition, the weight of the heart, lung, left and right kidney, spleen, liver and filled digestive track was recorded. Bats were checked for ectoparasites first. These were separated into systematic classes and stored in 70\% ethanol. A few fleas of both sexes were left in potassium hydroxide (10\%) for 2 hours

Table 1 Morphometrical data of Myotis myotis $(n=30)$ from Gladenbach (Hesse)

\begin{tabular}{|c|c|c|c|c|c|c|c|}
\hline & Total weight $[\mathrm{g}]$ & \multicolumn{2}{|c|}{ Head-Body length [cm] } & \multicolumn{2}{|c|}{ Upper arm length [cm] } & \multicolumn{2}{|c|}{ Forearm length $[\mathrm{cm}]$} \\
\hline Min. & 7.310 & 4.9 & & 2.00 & & 4.00 & \\
\hline Max. & 14.239 & 6.8 & & 3.10 & & 5.80 & \\
\hline$\varnothing$ & $11.184( \pm 1.517)$ & $6.09( \pm 0.429)$ & & $2.56( \pm 0.28)$ & & $4.93( \pm 0.45)$ & \\
\hline & Heart [g] & Lung [g] & Kidney left [g] & Kidney right $[\mathrm{g}]$ & Spleen [g] & Liver [g] & ${ }^{*}$ Digestive track [g] \\
\hline Min. & 0.082 & 0.121 & 0.031 & 0.050 & 0.008 & 0.226 & 0.247 \\
\hline Max. & 0.217 & 0.286 & 0.085 & 0.096 & 0.099 & 0.595 & 0.932 \\
\hline$\varnothing$ & $0.138( \pm 0.027)$ & $0.201( \pm 0.041)$ & $0.067( \pm 0.011)$ & $0.072( \pm 0.011)$ & $0.053( \pm 0.020)$ & $0.400( \pm 0.094)$ & $0.551( \pm 0.091)$ \\
\hline
\end{tabular}

$\varnothing=$ average, ${ }^{*}$ filled, \pm standard deviation. 
at $95^{\circ} \mathrm{C}$ or 24 hours at $35^{\circ} \mathrm{C}$. Afterwards they were rinsed in xylol and stored in 70\% ethanol. Bats were then dissected and checked for endoparasites. Endoparasites used for morphological species identification were placed in Histofix overnight and stored in $70 \%$ ethanol. Parasites used for molecular species identification were preserved in absolute ethanol.

\section{Analysis of parasite diversity}

Species were identified and the quantitative parasitological data prevalence (P \%), abundance (A), intensity (I), mean intensity $(\mathrm{mI})$ and index of relative frequency (pi) were calculated following Bush et al. [20] (Table 2). Intensity of infection (I) is the number of individuals of a particular parasite species in a single infected host (expressed as a numerical range), whereas mean intensity of infection $(\mathrm{mI})$ is the average intensity. Mean abundance $(\mathrm{mA})$ is the total number of individuals of a particular parasite species in a sample of a particular host species divided by the total number of hosts of that species examined, including both infected and uninfected hosts [20]. The diversity of the metazoan parasite fauna was estimated using the Shannon-Weaver diversity index (Hs) and the evenness index (E) following Shannon \& Weaver [21]. Spearman's Rank test was used in order to analyze the relationship between the Index of Condition, body weight divided by forearm length (after Lourenco \& Palmeirim [15]), and the parasite intensity (number of parasites per host specimen) with ectoparasites and cestodes, respectively, using Graphpad Prism software version 5.01. During necropsy, muscle tissue samples for species identification and brain tissue samples for Lyssavirus identification were taken. The parasite list was compiled in consideration of all previously published literature.

\section{Species identification}

Genomic DNA was isolated and purified from small amounts of muscular tissue (10-20 mg) using an AcroPrep PALL 96-well glass fiber plate $(1 \mathrm{ml} ; 1 \mu \mathrm{m})$ according to the instructions provided by Ivanova et al. [22]. The cytochrome b genetic marker from Myotis sp. was amplified using primer Cyt-b FWN (5'-TGA-TGR-AAC-TTY-GGYTCY-CTY-YTA-GGA-RTY-T-3') and Cyt-b REV (5'-CCRATR-ATR-ATR-TAK-GGR-TRY-TCD-ACD-GGT-TG-3'). PCR-reaction $(50 \mu \mathrm{l})$ included $25 \mu \mathrm{l}$ Master-Mix (Peqlab Biotechnology $\mathrm{GmbH}$, Erlangen, Germany) containing dNTP, $\mathrm{MgCl}_{2}$, buffer and Taq polymerase, $3 \mu \mathrm{l}$ of each

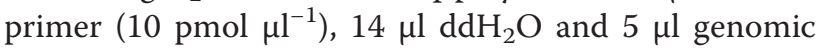
DNA. Each PCR reaction was performed in a thermocycler (Eppendorf, Germany) under the following conditions: one cycle of initial denaturation at $94^{\circ} \mathrm{C}$ for $120 \mathrm{sec}$, followed by 39 cycles of $94^{\circ} \mathrm{C}, 60 \mathrm{sec}$ (denaturation), $55^{\circ} \mathrm{C}$, $60 \mathrm{sec}$ (annealing) and $72^{\circ} \mathrm{C}$ for $75 \mathrm{sec}$ (extension). The final extension was carried out at $72^{\circ} \mathrm{C}$ for $5 \mathrm{~min}$. PCR products were examined on $1 \%$ agarose gels including a low range ladder marker (peqGOLD, Erlangen, Germany) to estimate the size of the PCR products. Successfully amplified PCR products were purified using the peqGOLD Cycle-Pure Kit (Peqlab Biotechnology $\mathrm{GmbH}$, Erlangen, Germany) following the instructions of the manufacturer. The purified products were sequenced by Seqlab (Goettingen GmbH, Germany) using primer Cyt-b FWN (5'-TGA-TGR-AAC-TTYGGY-TCY-CTY-YTA-GGA-RTY-T-3'). For species identification, obtained sequence data were compared with previously published Genbank data using the BLASTn algorithm [23]. Morphological parasite identification was carried out using the descriptions e.g. by Genov et al. [24], Brinck-Lindroth \& Smit [25], Tian \& Jin [26], Pocora et al. [27].

Table 2 Parasitological data of Myotis myotis $(n=30)$ from Gladenbach (Hesse)

\begin{tabular}{|c|c|c|c|c|c|c|c|c|}
\hline Species & $\mathrm{P}[\%]$ & A & $\mathrm{ml}$ & $I$ & pi & St & $\mathrm{Hs}$ & $\mathrm{E}$ \\
\hline \multicolumn{9}{|l|}{ Cestoda } \\
\hline Vampirolepis balsaci & 70 & 4.1 & 5.8 & $1-18$ & 1.212 & a & & \\
\hline \multicolumn{9}{|l|}{ Nematoda } \\
\hline Molinostrongylus alatus & 3.3 & 0.03 & 1 & 1 & 0.009 & a & & \\
\hline \multicolumn{9}{|l|}{ Arachnida } \\
\hline Ichoronyssus scutatus & 100 & 72 & 72 & $5-165$ & 21.126 & $\mathrm{a}, \mathrm{l}$ & \multirow{4}{*}{0.854} & \\
\hline Steatonyssus periblepharus & 100 & 228.6 & 228.6 & $26-1288$ & 67.077 & $\mathrm{a}, \mathrm{l}$ & & 0.41 \\
\hline Spinturnix myoti & 100 & 8.1 & 8.1 & $1-17$ & 2.390 & $\mathrm{a}, \mathrm{n}$ & & \\
\hline Ixodes ricinus & 3.3 & 0.03 & 1 & 1 & 0.009 & I & & \\
\hline \multicolumn{9}{|l|}{ Insecta } \\
\hline Cimex dissimilis & 83.3 & 2.8 & 3.3 & $1-17$ & 0.821 & $\mathrm{a}, \mathrm{l}$ & & \\
\hline Ischnopsyllus octactenus & 13.3 & 0.13 & 1 & 1 & 0.039 & $\mathrm{a}$ & & \\
\hline
\end{tabular}




\section{Lyssavirus identification}

Brain tissue of the 30 juvenile $M$. myotis and eight additional juvenile specimens from the same collecting point were checked for Lyssavirus infection using a direct immunofluorescence test (IFT/FAT). The eight additional specimens were in the same visible condition and age, and were also collected on July 21, 2012. These included half males and half females. Tests were carried out following the official guidelines of the Federal Research Institute for Animal Health, Friedrich-Loeffler-Institute [28].

\section{Review methodology}

To compile a parasite-host list as complete as possible, we searched PubMed, Medline, SciELO and Google Scholar for publications that contain records of Myotis species and associated parasite species as well as locality of the record from Europe. Foremost, we used primary literature. If description was unambiguous and met our requirements, we also included records mentioned in reviews and other secondary literature.

\section{Results \\ Morphometric data and species identification of Myotis myotis}

The sympatric sibling species Myotis myotis and $M$. blythii are difficult to distinguish based on morphological characters, especially as juveniles. They can roost together [29]. Therefore, cyt-b segment analysis was used. In total, 27 Myotis specimens could be sequenced successfully and Blast-analyses revealed $99-100 \%$ identity with a sequence of M. myotis from Romania (Acc.: GU817367.1), suggesting that our specimens belong to the same species. We identified 27 specimens as $M$. myotis which were used for parasitological analysis. The remaining three specimens did not provide enough DNA for sequencing but were assumed to be the same species. The obtained sequences of $M$. myotis were deposited in Genbank under the accession numbers KJ765363-KJ765389. Morphometric data of the examined Myotis specimens are summarized in Table 1. Head-body length, fore arm length, upper arm length and total weight of bats were normally distributed (D'Agostino \& Pearson normality test; $\mathrm{p}=0.181 ; 0.839 ; 0.720 ; 0.840$ ). Because the colony was checked frequently and bats were collected within 48 hours, the state of preservation was good. The bats showed nearly no visible signs of decay, e.g. dried eyes or mucosa. We have secured the condition based on the findings of well-developed muscle and fat tissue we observed during section.

\section{Parasites of Myotis myotis from Gladenbach (Hesse)}

All bats in the sample were parasitized. Eight parasite species Ixodes ricinus, Ischnopsyllus octactenus, Ichoronyssus scutatus, Steatonyssus periblepharus, Spinturnix myoti, Cimex dissimilis, Molinostrongylus alatus and Vampirolepis balsaci were recorded from these M. myotis (Table 2). We were able to record $S$. periblepharus I. scutatus, $V$. balsaci and $M$. alatus as new records from $M$. myotis in Germany. All specimens were infected with the mite species I. scutatus, S. myoti (Figure 1) and S. periblepharus. Infection parameters of $C$. dissimilis (Figure 1) and $V$. balsaci reached a prevalence of $83.3 \%$ and $70 \%$, respectively. We were also able to find I. octactenus (Figure 2) on $13.3 \%$ of the individuals. Ixodes ricinus and $M$. alatus each showed a prevalence of $3.3 \%$. Statistical analyses revealed no significant correlation between the index of condition [15] and the total ectoparasite as well as cestode parasite load of the bats (Spearman, non-parametric test: $\mathrm{P}=0.56$, $\mathrm{P}=0.68 ; \alpha=0.05$ ) (Figures 3 and 4 ). No sex-based differences in parasitism patterns (total numbers of ecto-/ endoparasites) were observed (two-tailed, Mann-Whitney U-test; $\mathrm{P}=0.22 ; \alpha=0.05$ ).

\section{Virus detection}

The brain tissue of the 30 juvenile greater mouse-eared bats and additional 8 specimens from the same roosting place showed no positive results by using the direct immunofluorescence test (IFT). There was no evidence of Lyssavirus-specific antigen.

\section{Parasites of Myotis in Europe}

Based on the previously published literature a total of 98 parasite species have been reported from the 14 resident Myotis species in Europe (Table 3). Most of the species were recorded in Germany, Italy, Poland and Slovakia (Figure 5). In some cases detailed specifications of location were missing. The list includes records of 42 parasitic arachnids, 30 insects, 13 nematodes, 8 digeneans and 4 cestodes. With about $43 \%(n=42)$ of the species, Arachnida is the most species rich class in the list of parasites. It is represented by the orders Mesostigmata $(n=27)$, Ixodida $(n=6)$, Sarcoptiformes $(n=4)$, Prostigmata $(\mathrm{n}=3)$ and Astigmata $(\mathrm{n}=1)$. The second largest class is Insecta, with about ca. 37\% $(n=30)$. In Europe three orders parasitize Myotis: flies (Diptera) (Superfamily Hippoboscoidea) $(n=14)$, fleas (Siphonaptera) $(n=13)$ and bugs (Heteroptera) $(n=3)$. The phylum Nematoda is represented by 13 species (ca. 13\%). Amongst these is the class Secernentea with the orders Strongylida and Spirurida, represented respectively by four and three species. The other six species belong to the class Adenophorea, order Enoplida. The class Cestoda is represented by four species (ca. 4\%) which all belong to the order Cyclophyllidea. Eight species (ca. 8\%) belonging to the order Plagiorchiida of the class Trematoda parasitize Myotis in Europe. Our calculations show that 12 of the 14 Myotis species serve as hosts of at least 5 different parasite species. Compared to other Myotis species from Europe, the parasite fauna of $M$. myotis shows the highest diversity. 

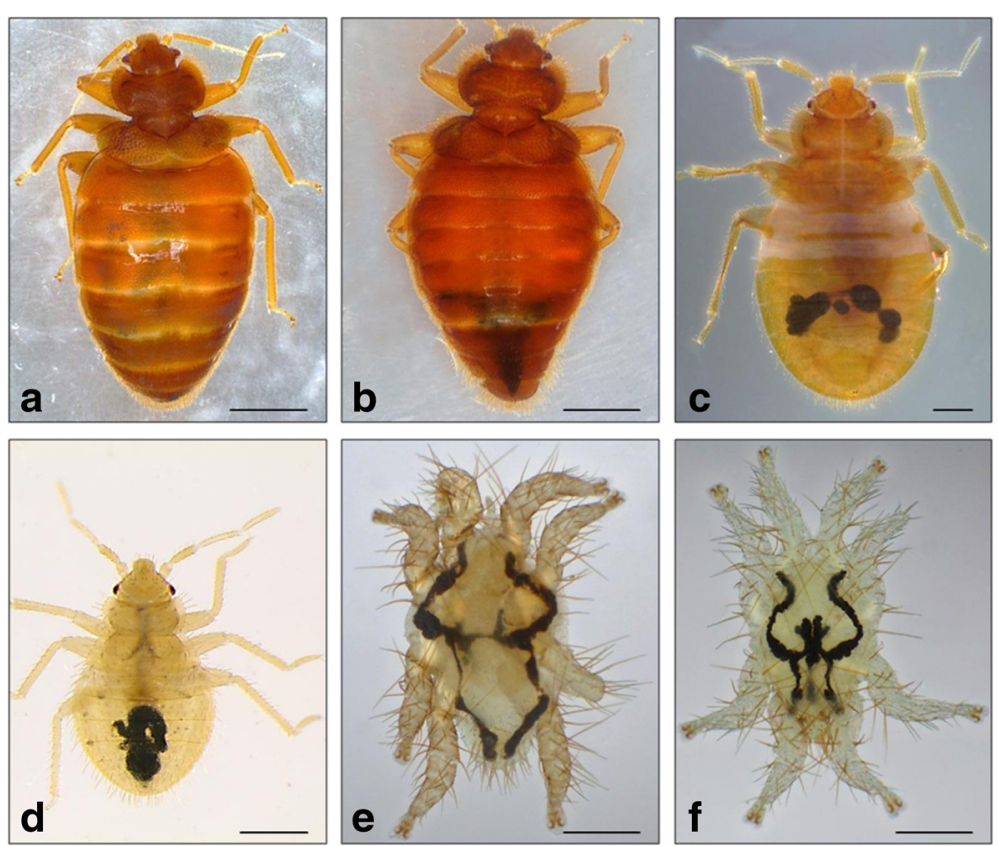

Figure 1 Bugs and spinturnicid mites of Myotis myotis from Gladenbach (Hesse). a-d Cimex dissimilis (Heteroptera, bugs), e-f Spinturnix myoti (Mesostigmata, mites). Habitus, dorsal view. Light micrographs. a) female, adult b) male, adult c) older larval stage d) younger larval stage. In bugs ingested blood (dark spots) in the digestive track is well visible in both larval stages, but hardly visible in adult stages. Scale bars: $\mathbf{a}-\mathbf{b}=1 \mathrm{~mm}$, c- $\mathbf{d}=500 \mu \mathrm{m}, \mathbf{e}-\mathbf{f}=200 \mu \mathrm{m}$.

\section{Discussion}

\section{Field study}

\section{Condition of juveniles and virus detection}

The specimens investigated were not weaned off juveniles born in 2013. The fur of the specimens was fully developed; however, they had never been out of the roosting habitat. This was indicated by the short forearm length with less than $58 \mathrm{~mm}$, which is considered the minimum length necessary for flight according to Kulzer [66]. The high parasitic infections of juveniles found here is a rather common phenomenon in bats. Juvenile M. myotis are more frequently infected than adults, most likely due to the fact that the immune system of juvenile bats is hardly developed [67]. Grooming, considered one of the most effective mechanisms of ectoparasite reduction, is also ineffective at a low age [68], thus, the harm for juvenile specimens is expected to be higher than in adult specimens. However, the juvenile M. myotis sampled here seem to have compensated for the harm caused by the parasites because of the good nutritional condition. No correlation between parasite burden and condition of host was found (Figure 3 and 4). Our assumption is supported by experimentally quantified results as described further below. The results of testing for viruses yielded no indication of a Lyssavirus specific antigen. However, as the infection rates of European M. myotis populations vary according to the type of Lyssavirus involved as well as between regions and through time
$[3,10]$, infection rates in Germany might still be worth investigating.

\section{Parasite parameters}

Sampled M. myotis were heavily parasitized (Table 2). The intensities and therewith indices of relative frequency (pi \%) varied strongly within the eudominant [69] species I. scutatus, S. periblepharus, S. myoti, C. dissimilis and $V$. balsaci. S. periblepharus was the most dominant species with up to 1,288 specimens on a single host, which is the highest amount of this parasite species found in bats so far. In addition, we estimate that the number of mobile ectoparasites in living $M$. myotis is higher because ectoparasites leave the host after death. I. octactenus and $C$. dissimilis are very mobile and we estimate the highest differences of parasite burden

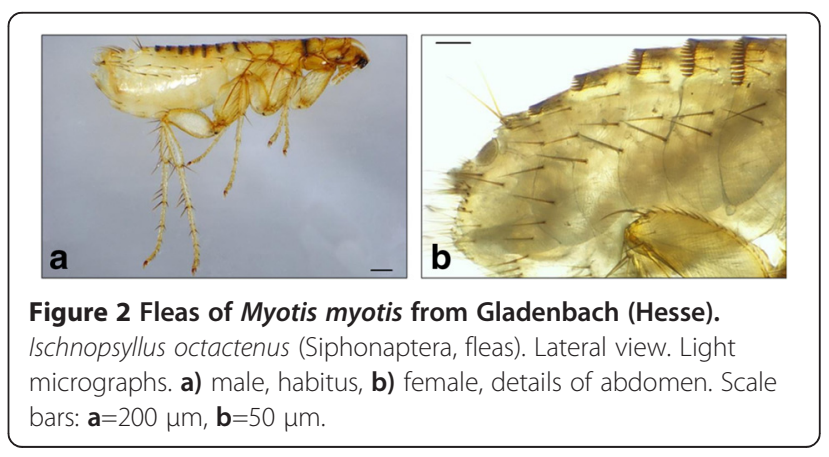




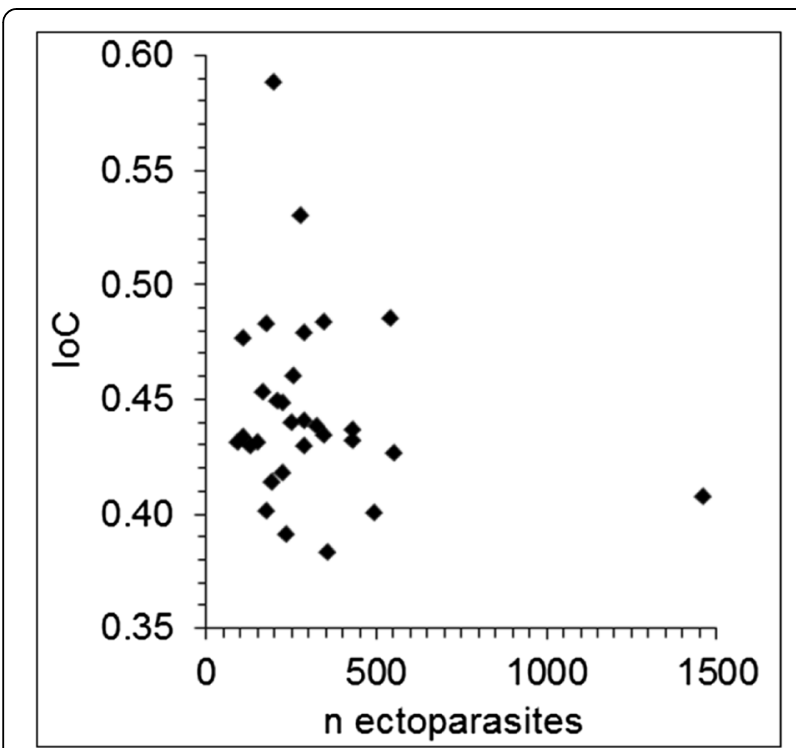

Figure 3 Relationship between ectoparasite loads and the index of condition of hosts. A correlation could not be observed. A single host was parasitized by more than 1,462 parasites. IoC=Index of Condition (body weight divided by forearm length).

compared to living bats within these species. I. ricinus, I. scutatus, and $S$. periblepharus are less mobile, $S$. myoti is hardly mobile because of the high grade of specialisation. We estimate that the infection rates differ slightly within the first three species and hardly differ in $S$. myoti. Therefore the results are nearly transferable to living M. myotis within this species. Despite the

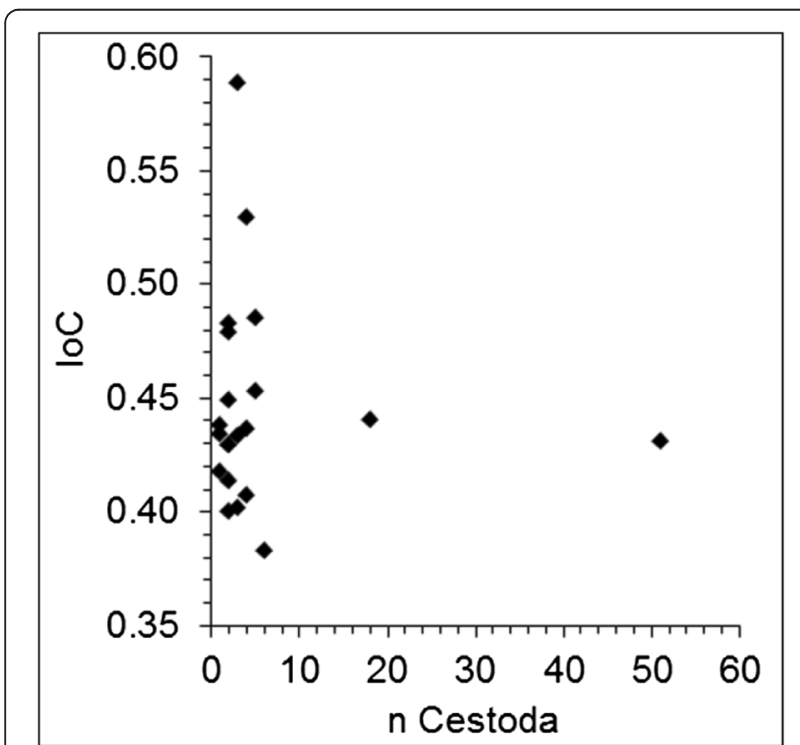

Figure 4 Relationship between cestode loads and the index of condition of hosts. A correlation could not be observed. Two hosts were parasitized by 51 and 18 Vampirolepis balsaci (cestode), respectively. $\mathrm{loC}=$ Index of Condition (body weight divided by forearm length). extreme infection rates found in one individual, the parasite fauna and intensities found here coincide with a regular parasite pattern within a $M$. myotis population [16]. Therefore, especially juvenile $M$. myotis form the habitat for a wide range of different associated species and are an integral part of the ecosystem. A sex-specific difference in the degree of parasitism in juvenile $M$. myotis was absent which confirmed earlier findings by Christe et al. [68]. Bigger parasites are likely to remove more energy from the host. Hence, the index of relative frequency and parasite size must be taken into account to assess damage to the host. Giorgi et al. [70] postulated a rise in overall metabolism rate of $M$. myotis of approx. $0.5 \%$ with each additional Spinturnix myoti individual. However, in contrast to the lab-based study by Giorgi et al. [71], a correlation between mite infections and index of condition in free-living $M$. myotis bats was not observed in this study (Figures 3 and 4).

\section{Ectoparasites}

Generally, the high infection rates with ectoparasitic mites can be explained by the typical phenological process of parasitism in M. myotis [16]. The infection rates found here during July depict probably the highest infection rates that can be expected during the year. Spinturnix mites are strictly Microchiroptera specific parasites [67]. S. myoti, the most common Spinturnix species found, uses M. myotis as the main host, but it also accepts other Myotis species and genera such as Pipistrellus, Plecotus and Vespertilio $[14,17]$. The prevalence found here is comparable to a study on juvenile $M$. myotis populations from Germany and Portugal where slightly lower Spinturnicidae (without further determination) prevalence of $94.7 \%$ and $96.6 \%$ were found [16]. Christe et al. [71] were also able to record comparable prevalence of $99.5 \%$ from $S$. myoti in juvenile M. myotis from Switzerland. High prevalence of Spinturnix mites are a result of their extreme specialisation and adaptation to bats as hosts. Spinturnix females possess an evolutionary advantage compared to other parasites, in that they bear deuteronymphs with shorter development on hosts rather than laying eggs [67]. Contrastingly, parasitism of the two rare species (in the sense of Zander [69]) Ischnopsyllus octactenus and Ixodes ricinus were under represented in the bat population.

\section{Endoparasites}

Regarding the species composition of endo-and ectoparasites, our results vary widely from other observations, e.g. from Slovakia or other populations in Germany $[12,16]$. Most of the former recorded parasite species belong to completely different systematic taxa (Table 3 ). Based on our own practical work as well as the information based on other literature (see section further below on parasites of European Myotis populations), M. myotis 
Table 3 Records of metazoan parasites of Myotis from Europe

\begin{tabular}{|c|c|c|}
\hline Host & Occurence parasite with host & Citation \\
\hline Myotis alcathoe & $\begin{array}{l}\text { Arachnida: Ixodes ariadnae (HU) Ixodes simplex (SK) Ixodes vespertilionis } \\
(\mathrm{SK}, \mathrm{RO}) \text { Spinturnix mystacinus }(\mathrm{CH}, \mathrm{SK}) \text { Insecta: Basilia italica (SK) }\end{array}$ & {$[30-33]$} \\
\hline Myotis aurascens & Insecta: Basilia mongolensis nudior (GR) & {$[34]$} \\
\hline & $\begin{array}{l}\text { Arachnida: Argas vespertilionis (IT) Ixodes ricinus (PL) Macronyssus } \\
\text { diversipilis (GB) Spinturnix bechsteini }(\mathrm{CH}, \mathrm{DE}, \mathrm{FR}, \mathrm{IT}, \mathrm{PL}, \mathrm{SK})\end{array}$ & \\
\hline Myotis bechsteinii & $\begin{array}{l}\text { Insecta: Basilia nana (DE,SK) Cimex pipistrelli (n.d.) Ischnopsyllus } \\
\text { hexactenus (DE) Ischnopsyllus octactenus (DE) Ischnopsyllus simplex } \\
\text { (n.d.) Nycteribia kolenatii (n.d.) Nematoda: Aonchotheca eubursata } \\
\text { (HU) Molinostrongylus alatus (n.d.) Molinostrongylus vespertilionis (n.d.) }\end{array}$ & {$[24,30,32,35-42]$} \\
\hline \multirow{3}{*}{ Myotis blythii } & $\begin{array}{l}\text { Arachnida: Acarus penetrans (nomen dubia) (IT) Argas vespertilionis } \\
\text { (SK) Binuncus parenzani (IT) Eyndhovenia euryalis oudemansi (n.d.) } \\
\text { Hirstionyssus albatus (IT) Hystrionyssus arcuatus (IT) Ixodes ariadnae } \\
\text { (HU) Ixodes vespertilionis (SK) Macronyssus granulosus (IT) Macronyssus } \\
\text { rhinolophi (IT) Microtrombidium italicum (IT) Spinturnix acuminata (n.d.) } \\
\text { Spinturnix myoti (CH,SK) Spinturnix kolenatii (n.d.) Spinturnix vespertilionis (IT) }\end{array}$ & \multirow{3}{*}[24,30,32-35,43-46]{} \\
\hline & $\begin{array}{l}\text { Insecta: Basilia nana (n.d.) Ischnopsyllus intermedius (n.d.) Nycteribia latreillei (GR) } \\
\text { Nycteribia vexata (IT) Nycteribia pedicularia (IT) Nycteribia schmidlii schmidlii (IT) } \\
\text { Nycteridopsylla eusarca (n.d.) Penicillidia conspicua (n.d.) Penicillidia dufourii (CY,GR,IT) }\end{array}$ & \\
\hline & $\begin{array}{l}\text { Nematoda: Aonchotheca moraveci (ES) Litomosa ottavianii (IT) Molinostrongylus } \\
\text { alatus (BG) Molinostrongylus vespertilionis (n.d.) Physaloptera brevivaginata } \\
\text { (ES) Trichuroides chiropteri (IT) }\end{array}$ & \\
\hline
\end{tabular}
(ES) Trichuroides chiropteri (IT)

Myotis brandtii mystacinus (CH,DE,SK) Steatonyssus cavus (LV) Steatonyssus periblepharus (DE)

Insecta: Basilia italica (n.d.) Cimex pipistrelli (n.d.) Ischnopsyllus hexactenus (DE,LV) Ischnopsyllus octactenus (DE) Ischnopsyllus simplex/mysticus (not clearly separable) (DE) Ischnopsyllus simplex (DE) Myodopsylla trisellis (LV) Nycteribia kolenatii (DE)

Arachnida: Hystrionyssus arcuatus (IT) Spinturnix psi (FR) Steatonyssus periblepharus (DE,HU)

Insecta: Nycteribia kolenatii (IT) Nycteribia latreillei (IT) Nycteribia pedicularia (CY,GR,IT) Nycteribia schmidlii schmidlii (GR,IT) Penicillidia conspicua (IT)

Myotis capaccinii Penicillidia dufourii (GR,IT) Phtiridium biarticulatum (IT) Rhinolophopsylla unipectinata (IT)

Digenea: Lecithodendrium linstowi (IT) Lecithodendrium rotundum (IT)

Plagiorchis vespertilionis (IT)

Nematoda: Aonchotheca moraveci (ES)

Arachnida: Argas vespertilionis (PL) Macronyssus crosbyi (LV) Macronyssus

corethroproctus (PL) Spinturnix acuminata (n.d.) Spinturnix andegavinus

(n.d.) Spinturnix dasycnemi (SK) Spinturnix myoti (LV,PL) Spinturnix

mystacinus (n.d.) Steatonyssus cavus (LV) Steatonyssus periblepharus (PL)

Insecta: Basilia nana (n.d.) Cimex pipistrelli (n.d.) Ischnopsyllus hexactenus

(DE,LV) Ischnopsyllus intermedius (DE) Ischnopsyllus simplex (n.d.) Ischnopsyllus

Myotis dasycneme variabilis (DE) Myodopsylla trisellis (LV) Nycteribia biarticulata (LV) Nycteribia

kolenatii (n.d.) Nycteribia pedicularia (LV) Nycteridopsylla pentactena (DE)

Digenea: Plagiorchis mordovii (PL)

Cestoda: Vampirolepis balsaci $(\mathrm{PL})$ Vampirolepis skrjabinariana $(\mathrm{PL})$

Nematoda: Capillaria italica (HU) Molinostrongylus alatus (n.d.)

Molinostrongylus vespertilionis (n.d.)

Arachnida: Alabidocarpus intercalatus (GB) Macronyssus crosbyi (LV) Macronyssus diversipilis (GB) Macronyssus ellipticus (GB) Macronyssus flavus (CZ) Notoedres myoticola (GB) Nycteridocoptes poppei (GB)

Myotis daubentonii Spinturnix acuminata (n.d.) Spinturnix andegavinus $(\mathrm{CH}, \mathrm{CZ}, \mathrm{DE}, \mathrm{PL}, \mathrm{SK})$ Spinturnix helvetiae (SK), Spinturnix kolenatii (n.d.) Spinturnix myoti (LV), Steatonyssus cavus (LV) Steatonyssus spinosus (n.d.) 
Table 3 Records of metazoan parasites of Myotis from Europe (Continued)

\begin{tabular}{|c|c|c|}
\hline & $\begin{array}{l}\text { Insecta: Basilia nana (n.d.) Basilia nattereri (SK) Cimex pipistrelli (n.d.) } \\
\text { Ischnopsyllus intermedius (n.d.) Ischnopsyllus hexactenus (DE,LV) Ischnopsyllus } \\
\text { mysticus (DE) Ischnopsyllus octactenus (DE) Ischnopsyllus simplex (DE,SK) } \\
\text { Ischnopsyllus variabilis (n.d.) Nycteribia kolenatii (DE,IT,SK) Nycteribia latreillii } \\
\text { latreillii (IT) Nycteribia pedicularia (LV,IT) Nycteribia schmidlii schmidlii (IT) } \\
\text { Nycteribia vexata (IT) Penicillidia monoceros (DE) Phthiridium biarcticulatum (n.d.) }\end{array}$ & \\
\hline & $\begin{array}{l}\text { Digenea: Lecithodendrium linstowi (BY) Plagiorchis vespertilionis (BY,IT) } \\
\text { Prosthodendrium chilostomum (BY) Prosthodendrium longiforme (BY) } \\
\text { Nematoda: Aonchotheca eubursata (HU) Capillaria romana (BY) } \\
\text { Capillaria speciosa (IT) Molinostrongylus alatus (n.d.), Molinostrongylus } \\
\text { spasskii (n.d.), Molinostrongylus tipula (n.d.) Molinostrongylus vespertilionis (n.d.) }\end{array}$ & \\
\hline \multirow{4}{*}{ Myotis emarginatus } & $\begin{array}{l}\text { Arachnida: Eyndhovenia euryalis (FR,PL) Macronyssus rhinolophi (n.d.) } \\
\text { Steatonyssus periblepharus (DE), Spinturnix emarginata (ES,PL,SK) }\end{array}$ & \multirow{4}{*}[30,32,35,49,51,56,57]{} \\
\hline & $\begin{array}{l}\text { Insecta: Basilia nana (n.d.), Basilia italica (n.d.) Cimex pipistrelli (n.d.) } \\
\text { Ischnopsyllus emarginatus (n.d.) Ischnopsyllus simplex (n.d.) Penicillidia } \\
\text { dufourii (IT) Phthiridium biarcticulatum (n.d.) Rhinolophopsylla unipectinata (n.d.) }\end{array}$ & \\
\hline & $\begin{array}{l}\text { Digenea: Lecithodendrium linstowi (AT) Prosthodendrium aelleni (AT) } \\
\text { Prosthodendrium chilostomum (AT) }\end{array}$ & \\
\hline & Cestoda: Myotolepis grisea (AT) & \\
\hline \multirow{6}{*}{ Myotis myotis } & $\begin{array}{l}\text { Arachnida: Acarus penetrans (nomen dubia) (IT) Argas transgariepinus } \\
\text { (IT) Argas vespertilionis (DE) Ichoronyssus scutatus (SK, o.r./n.a.r.) Ixodes } \\
\text { ricinus (DE,PL,O.r.) Ixodes simplex (DE,IT,PL) Ixodes trianguliceps (PL) Ixodes } \\
\text { vespertilionis (IT,RO,SK) Macronyssus cyclaspis (n.d.) Macronyssus diversipilis } \\
\text { (n.d.) Macronyssus ellipticus (GB) Macronyssus flavus (CZ) Macronyssus } \\
\text { granulosus (IT) Macronyssus rhinolophi (IT) Microtrombidium italicum (IT) } \\
\text { Nycteridocoptes poppei. (DE) Nycteriglyphus tuerkorum (?) (CZ) Radfordia } \\
\text { sicula (IT) Spinturnix acuminata (n.d.) Spinturnix myoti (CH,DE,IT,PL,SK,o.r.) } \\
\text { Spinturnix mystacina (n.d.) Spinturnix psi (IT) Spinturnix vespertilionis (IT) } \\
\text { Steatonyssus periblepharus (IT,o.r.) Steatonyssus spinosus (DE,PL,SK) } \\
\text { Trombicula sp. (DE) }\end{array}$ & \multirow{6}{*}[12-14,24,30,32,37-39,41,45,49,51,54-59]{} \\
\hline & $\begin{array}{l}\text { Insecta: Basilia nana (SK) Basilia nattereri (n.d.) Cimex dissimilis (DE,o.r.) } \\
\text { Cimex lectularius (DE) Cimex pipistrelli (SK) Ischnopsyllus elongatus (DE) } \\
\text { Ischnopsyllus hexactenus (DE) Ischnopsyllus intermedius (DE,IT) Ischnopsyllus } \\
\text { octactenus (DE,o.r.) Ischnopsyllus simplex (DE) Ischnopsyllus variabilis (DE) } \\
\text { Nycteribia kolenatii (DE,IT) Nycteribia latreillei (DE,IT,SK) Nycteribia pedicularia } \\
\text { (IT) Nycteribia schmidlii schmidlii (IT) Nycteribia vexata (DE,IT,SK) Nycteridopsylla } \\
\text { eusarca (DE,IT) Nycteridopsylla longiceps (DE) Nycteridopsylla pentactena } \\
\text { (DE) Penicillidia dufourii (DE,IT,SK) }\end{array}$ & \\
\hline & Phthiridium biarcticulatum (IT) Rhinolophopsylla unipectinata (n.d.) & \\
\hline & $\begin{array}{l}\text { Digenea: Lecithodendrium linstowi (AT) Plagiorchis vespertilionis (AT) } \\
\text { Prosthodendrium chilostomum (AT) }\end{array}$ & \\
\hline & $\begin{array}{l}\text { Cestoda: Cycloskrjabinia taborensis (IT) Vampirolepis balsaci (AT,HU, } \\
\text { n.a.r./o.r.) Myotolepis grisea (AT,HU) Vampirolepis acuta (HU) }\end{array}$ & \\
\hline & $\begin{array}{l}\text { Nematoda: Aonchotheca moraveci (ES) Litomosa desportesi (HU) Litomosa } \\
\text { ottavianii (IT) Molinostrongylus alatus ( }{ }^{*} \mathrm{BA}, \mathrm{BG}, \mathrm{CH}_{,}{ }^{*} \mathrm{HR},{ }^{*} \mathrm{ME},{ }^{*} \mathrm{MK},{ }^{*} \mathrm{RS},{ }^{*} \mathrm{SI}, \mathrm{o} . \mathrm{r} . / \text { n.a.r.) } \\
\text { Molinostrongylus spasskii (n.d.) Molinostrongylus vespertilionis (n.d.) } \\
\text { Trichuroides chiropteri (IT) }\end{array}$ & \\
\hline \multirow{4}{*}{ Myotis mystacinus } & $\begin{array}{l}\text { Arachnida: Argas vespertilionis (DE,PL) Ixodes sp. (LV) Ixodes vespertilionis } \\
\text { (SK) Macronyssus ellipticus (GB) Macronyssus flavus (DE) Spinturnix } \\
\text { kolenatii (n.d.) Spinturnix myoti (LV,SK) Spinturnix mystacinus (DE, CH,PL) } \\
\text { Steatonyssus periblepharus (DE,GB) Steatonyssus spinosus (n.d.) }\end{array}$ & \multirow{4}{*}[14,17,24,30,32,35,39,40,43,47,49-51,55,56]{} \\
\hline & $\begin{array}{l}\text { Insecta: Basilia nana (n.d.) Basilia nattereri (n.d.) Basilia italica (IT,SK) } \\
\text { Cimex pipistrelli (n.d.) Ischnopsyllus hexactenus (DE,LV) Ischnopsyllus } \\
\text { mysticus (DE) Ischnopsyllus octactenus (DE) Ischnopsyllus simplex (DE,SK) } \\
\text { Ischnopsyllus variabilis (n.d.) Myodopsylla trisellis (LV) Nycteribia kolenatii } \\
\text { (n.d.) Nycteribia pedicularia (IT) Nycteridopsylla longiceps (DE) Nycteridopsylla } \\
\text { pentactena (DE) Digenea: Lecithodendrium linstowi (AT), Plagiorchis } \\
\text { vespertilionis (IT) Prosthodendrium chilostomum (AT) }\end{array}$ & \\
\hline & $\begin{array}{l}\text { Nematoda: Molinostrongylus alatus (n.d.) Molinostrongylus spasskii } \\
\text { (n.d.) Molinostrongylus vespertilionis (n.d.) }\end{array}$ & \\
\hline & Cestoda: Vampirolepis balsaci (PL) & \\
\hline
\end{tabular}


Table 3 Records of metazoan parasites of Myotis from Europe (Continued)

\begin{tabular}{|c|c|c|}
\hline \multirow{5}{*}{ Myotis nattereri } & $\begin{array}{l}\text { Arachnida: Argas vespertilionis (DE) Ixodes vespertilionis (DE) Macronyssus } \\
\text { diversipilis (GB) Macronyssus ellipticus (GB) Macronyssus flavus (DE) Spinturnix } \\
\text { andegavinus (n.d.) Spinturnix myoti (DE,FR,SK) Spinturnix mystacinus (n.d.) } \\
\text { Spinturnix psi (n.d.) }\end{array}$ & \multirow{5}{*}[14,24,30,32-38,45,46,49,55,57,60]{} \\
\hline & $\begin{array}{l}\text { Insecta: Basilia nattereri (SK) Ischnopsyllus hexactenus (DE) Ischnopsyllus } \\
\text { intermedius (DE) Ischnopsyllus octactenus (DE) Ischnopsyllus simplex (DE,SK) } \\
\text { Ischnopsyllus variabilis (n.d.) Nycteribia kolenatii (n.d.) Nycteribia latreillei (n.d.) } \\
\text { Penicillidia dufourii (CY) }\end{array}$ & \\
\hline & $\begin{array}{l}\text { Digenea: Allassogonoporus amphoraeformis (BY) Mesotretes peregrinus (ES) } \\
\text { Plagiorchis koreanus (IT) Plagiorchis vespertilionis (IT) Prosthodendrium aelleni (AT) }\end{array}$ & \\
\hline & Cestoda: Myotolepis grisea (PL) Vampirolepis acuta (HU) & \\
\hline & $\begin{array}{l}\text { Nematoda: Aonchotheca eubursata (HU) Capillaria italica (HU,IT) } \\
\text { Molinostrongylus alatus (n.d.) }\end{array}$ & \\
\hline \multirow{3}{*}{ *Myotis oxygnathus } & $\begin{array}{l}\text { Arachnida: Ichoronyssus jacksoni (AT) Ichoronyssus scutatus (n.d.) } \\
\text { Macronyssus rhinolophi (n.d.) Steatonyssus spinosus (n.d.) }\end{array}$ & \multirow{3}{*}[36,47,48,57,61-63]{} \\
\hline & Nematoda: Litomosa desportesi (HU) Physaloptera brevivaginata (HU) & \\
\hline & Cestoda: Myotolepis grisea (HU) & \\
\hline Myotis punicus & Arachnida: Spinturnix myoti (IT,FR) & [64] \\
\hline
\end{tabular}

serves as host for a wide range of different parasite species. Within the group of endoparasites, Molinostrongylus alatus and Vampirolepis balsaci are of special interest. Both have not previously been recorded on $M$. myotis in Germany. Only little is known about their life cycle. Single host life cycles as well as vertical transfers are described for numerous nematodes, which probably also applies to $M$. alatus. The infestation rates of $M$. alatus in the sample was clearly lower $(\mathrm{I}=1)$ than in the few cases reported in the literature, e.g. a prevalence of $65.21 \%$ and intensity of 1-28 with $M$. myotis as a host, and a prevalence of $46.66 \%$ and intensity of 1-45 in the closely related M. blythii [24]. Even more surprising than the infestation of juvenile $M$. myotis with $M$. alatus is the occurrence of $V$. balsaci. Based on life cycles of other cestodes following strategies of transmission are possible: As in nearly all Cyclophyllidea, a life cycle involving at least two hosts can be assumed for $V$. balsaci. Intermediate hosts involved are most likely fleas, for example of the genera Ischnopsyllus and Nycteridopsylla, which are frequent parasites of $M$. myotis. Ischnopsyllus octactenus was found in the studied population from Hesse. As adult fleas are exclusively haematophagous, this mode of bat infection would necessarily entail an infection of larval fleas by ingesting eggs containing infectious larvae of $V$. balsaci. After metamorphosis into adult fleas an oral uptake of fleas by the bats would follow and complete the cestode life-cycle. Because the cestode and the possible intermediate host (I. octactenus) were found in the bat population, this way of transmission seems to be very likely. A similar infection pathway has been described for the double-pore tapeworm
(Dipylidium caninum) [72]. Apart from fleas, mites might be intermediate hosts for $V$. balsaci and be ingested during grooming with the plants that are fed on as described for other vertebrate cestodes [73]. However, as the studied M. myotis were still not weaned off and had probably never left the breeding burrow or showed grooming behaviour, this mode of infection does not explain the infections with $V$. balsaci. A further possibility is autoinfection through the oral uptake of embryonated eggs in the faeces. A similar life cycle of autoinfection with a single host has already been described in the related species Hymenolepis nana (syn. Vampirolepis) [74]. It is striking that the prevalence of $M$. alatus $(\mathrm{P}=3.3 \%)$ and V. balsaci $(\mathrm{P}=70 \%)$ are extremely different. One explanation could be the different modes of infection, with $V$. balsaci infections probably being more time-consuming than the supposed direct infection with $M$. alatus. Beside the two endoparasite species, I. scutatus and $S$. periblepharus (Arachnida, mites) are the four species with a new distribution record on M. myotis within Germany. Our findings of the four new parasite species that use $M$. myotis as a host show that new insights into the Myotis parasites are still common and more records can likely be expected.

\section{Parasites of Myotis in Europe European parasite fauna}

To obtain an overview of the parasite fauna of Myotis species in Germany and other European countries, available published records of metazoan parasites of all European Myotis species were collated. The eight recorded parasite 


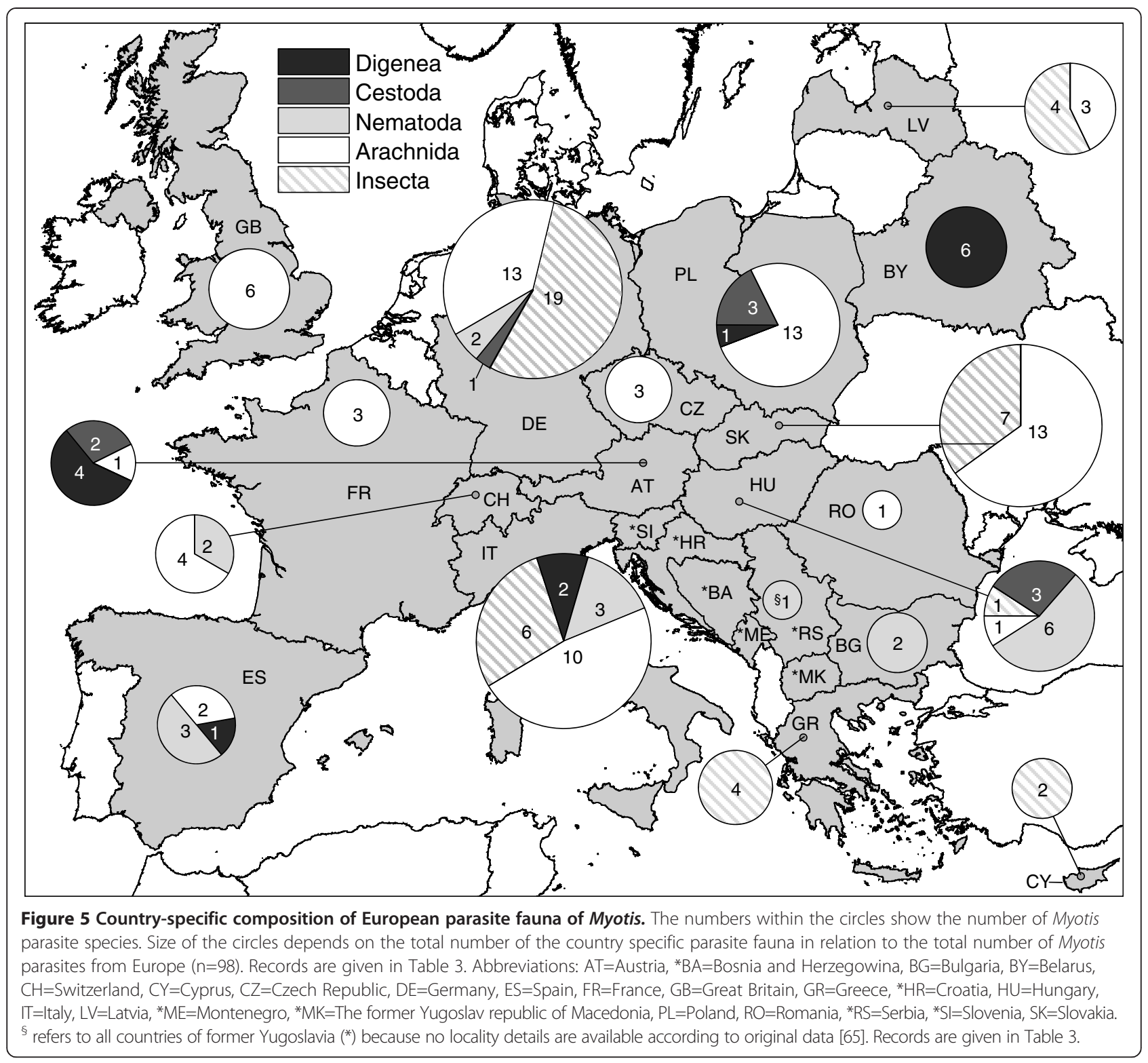

species that were found in the $M$. myotis population at the site in Gladenbach have already been noted to be parasites of M. myotis and of other Myotis species in Europe and are contributing about $25 \%$ of the parasite species on Myotis in Germany (Figure 5).

More than half of the species of the European parasite fauna of Myotis, currently 98 species, belong to a few, bat-specific genera of different classes. Arachnida of the order Mesostigmata, and within these the genera Macronyssus and Spinturnix are dominating the parasite fauna and are contributing approx. $21 \%$ to the parasite fauna of Myotis. Both genera occur as parasites of bats worldwide and sometimes reach an extreme degree of specialization on their hosts, e.g. with co-differentiation of Myotis punicus and its parasite Spinturnix myoti within different geographic lineages [64]. New species are regularly described in both genera, whereby the taxonomy has been affected by numerous changes $[26,27]$. The strictly bat specific Diptera and rather heteroxenous Siphonaptera are numerically also strongly represented among the European parasite fauna of Myotis. Similarly, most species of Cestoda belong to the bat-specific genus Vampirolepis. Based on our compilation we can state that the largest part of the digeneans, nematodes, arachnids, and insects was found only on a single host. With rising host numbers the number of parasite species parasitizing the same host decreases. Within the cestodes only one different species could be observed parasitizing the same host. The insect and arachnid species are the most diverse group within the European Myotis parasite fauna (Figure 6). 


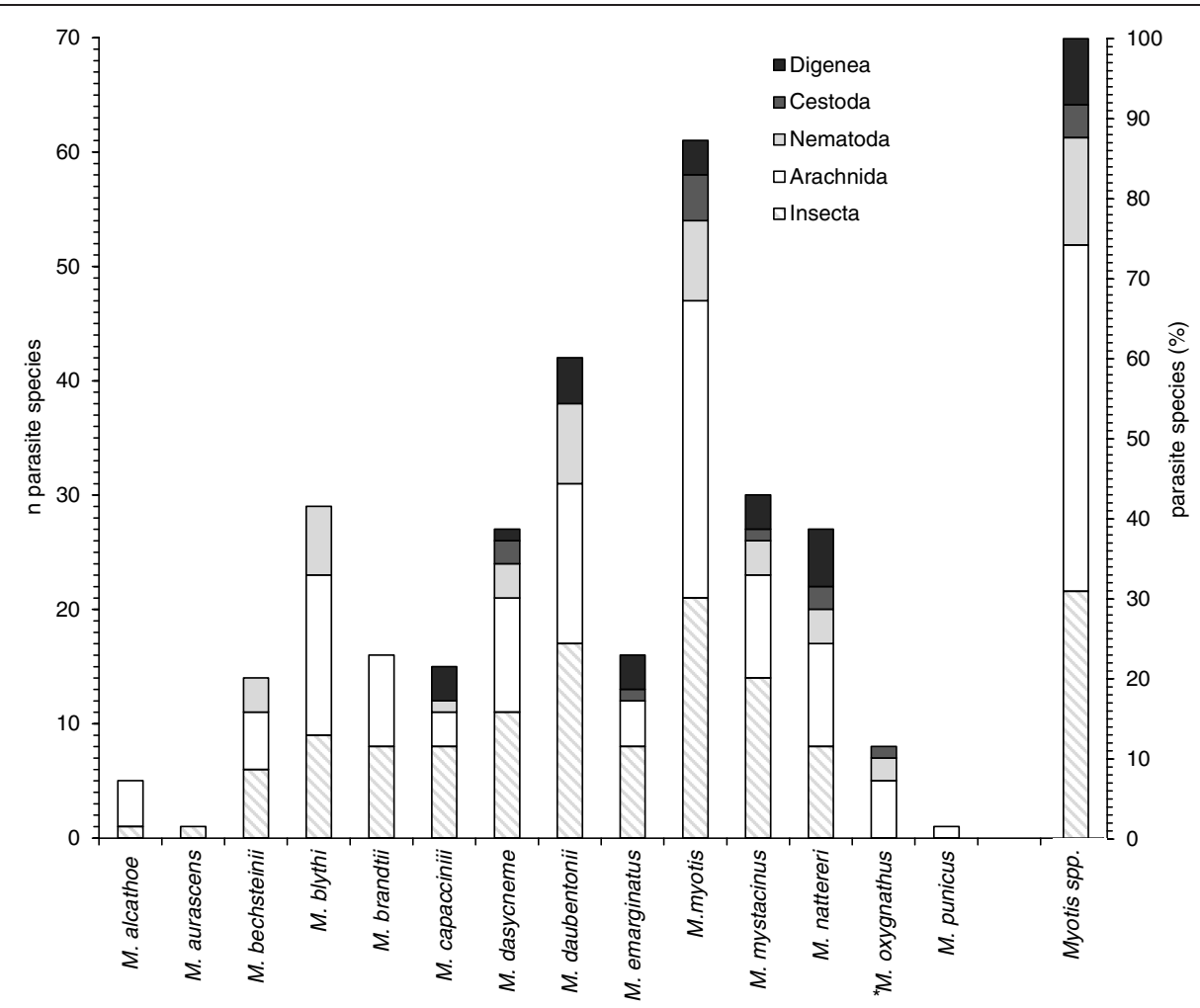

Figure 6 Host specification of European Myotis parasites. Shown are the total numbers and composition of the parasite species of each European Myotis species. The parasite species are combined in the five taxonomic groups. Furthermore, the percentages of the five taxonomic groups of all European Myotis parasites are shown. Myotis species are listed in alphabetical order. ${ }^{*}$ may not distinct on species level, treated as subspecies or synonym of M. blythii by some authors [62,63].

The highest number of parasites is reached by M. myotis; we assume this coincides with its great distribution pattern.

\section{Distribution pattern and composition of parasite species in Myotis}

The distribution pattern of bat parasites could be explained by the effects of the geographical barriers affecting bat distribution. The West Siberian Plain in the East forms a natural barrier between the European-Ural and SiberianFar Eastern complexes [75]. In the South, the Strait of Gibraltar functions as a natural barrier between Europe and Africa [6]. Geographical isolation within Europe is supposed to have led to species diversification within the few classes or genera of bat parasites that became established. Furthermore, the close relationship of parasite and host based on co-speciation at molecular level allows for the reconstruction of former distribution patterns of the host species [64]. Another factor that relates parasites to their host species is the mode of life of bats, i.e. their ability to fly reduces the likelihood of an infection with unspecific parasite species. For example infections with unspecific Ixodes (ticks) in bats are rather uncommon
[43]. Similarly, only two bat-specific families, Streblidae and Nycteribiidae (Diptera, superfamily Hippoboscoidea), constitute more than $68 \%$ of the bat parasites of South and Central America [76]. Additionally, the relatively high evolutionary age of bats compared to other mammals has probably played a role for the specific recent bat parasite composition. Earliest records date back to the early Eocene, but ancestors of modern bats might have already existed in the Paleocene as early fossil bats display the morphological characters of more recent bats [77]. Furthermore, Simmons [78] considered it likely that all recent bat families already existed by the late Eocene. This view is supported by the fact that remains of the oldest fossil of the bat-parasitic Streblidae are at least 15 million years old [79]. It seems reasonable to assume that not only ecological requirements and the way of life of early bats were similar to modern ones, but that also a specialized parasite fauna existed very early, worldwide and also in Europe. It was shown that the European wide composition of the Myotis parasite fauna is dominated by a few specific taxonomic groups in Europe. Based on these findings we propose that in the worldwide fauna of bat parasites a correspondingly long specialization 
on hosts might have similarly led to the dominance of particular taxonomic groups. This co-speciation led to the high diversity of species associated with bats. More studies covering a larger range are needed to clarify the today status of bat parasite species worldwide. Results would provide new insights into the parasite-host coevolution processes and help to better understand the ecology of bats.

\section{Conclusions}

The juvenile greater mouse-eared bats from the collecting point in Hesse (Germany) showed high parasite load and diversity. Due to the low age of the specimens, infection rates were high. Among the eight parasite species found, I. scutatus and S. periblepharus (Arachnida, mites), V. balsaci (Cestoda) and M. alatus (Nematoda) were recorded for the first time in Germany. The findings state that especially juvenile $M$. myotis serve as a habitat for a great range of parasite species. Therewith, they form an integral part of the ecosystem and contribute to species diversity in high amount. Especially the finding of endoparasitic cyclophyllidean cestodes that have usually at least a two-host lifecycle is, considering the stationary behaviour of the juvenile bats, rather unusual and suggests a non-predatory transmission mechanism (e.g. described for Hymenolepis nana). We assume that the number of parasites in juvenile Myotis is generally higher than in adults due to the only later acquired immune competence and behavioural adaptations. A complete overview of the European Myotis parasite fauna was given and revealed that a few parasite taxa dominate the recent European Myotis parasite fauna. Thus, a parasite-host co-specification in this unique taxonomic group is suggested.

\section{Competing interests}

The authors declare that they have no competing interests.

\section{Authors' contributions}

Research concept and design: RF, SK; Collection and analysis of data: RF; Writing the article RF, SK, TK; Molecular analysis: AW; Critical revision and final approval of the article: AL, JK. All authors read and approved the final manuscript.

\section{Acknowledgements}

We thank Conrad Freuling and Thomas Müller (Institute of Molecular Virology and Cell Biology, Federal Research Institute for Animal Health, Friedrich-LoefflerInstitute, Riems (Germany) for testing the Myotis myotis specimens for Lyssavirus infections. We thank Christian Melaun, Goethe-University (GU), Frankfurt/Main (Germany) for technical and Pascal Knodt for practical assistance.

\section{Declaration}

We declare that the conducted study complies with German laws. There is no conflict of interest with species conservation guidelines. The collection of samples was carried out in accordance with the property owner and the responsible environmental representative.

\section{Author details}

${ }^{1}$ Goethe-University (GU), Institute for Ecology, Evolution and Diversity; Senckenberg Biodiversity and Climate Research Centre (SBiK-F), Senckenberg Gesellschaft für Naturforschung (SGN), Max-von-Laue-Str. 13, Frankfurt am Main D-60438, Germany. ${ }^{2}$ Senckenberg German Entomological Institute (SDEI), Eberswalder Str. 90, Muencheberg D-15374, Germany.
Received: 9 October 2014 Accepted: 31 January 2015

Published online: 15 February 2015

\section{References}

1. Volleth M, Eick G. Chromosome evolution in bats as revealed by FISH: The ongoing search for the ancestral chiropteran karyotype. Cytogenet Genome Res. 2012;137:165-73.

2. Datzmann T, Von Helversen O, Mayer F. Evolution of nectarivory in phyllostomid bats (Phyllostomidae Gray, 1825, Chiroptera: Mammalia). BMC Evol Biol. 2010;10:1-14.

3. King AA, Haagsma J, Kappeler A. Lyssavirus infections in European bats. In: King AA, Fooks AR, Aubert M, Wandeler Al, editors. Historical perspective of rabies in Europe and the Mediterranean Basin. Paris: World Organisation for Animal Health; 2004. p. 221-41.

4. Hutson AM, Mickleburgh SP, Racey PA. Microchiropteran bats: global status survey and conservation action plan. Switzerland and Cambridge: IUCN; 2001.

5. Stadelmann B, Jacobs DS, Schoeman C, Ruedi M. Phylogeny of African Myotis bats (Chiroptera, Vespertilionidae) inferred from cytochrome b sequences. Acta Chiropterol. 2004;6:177-92.

6. Castella V, Ruedi M, Excoffier L, Ibáñez C, Arlettaz R, Hausser J. Is the Gibraltar Strait a barrier to gene flow for the bat Myotis myotis (Chiroptera: Vespertilionidae)? Mol Ecol. 2000;9:1761-72.

7. Kemenesi G, Dallos B, Görföl T, Boldogh S, Estok P, Kurucz K, et al. Novel European lineages of bat astroviruses identified in Hungar. Acta Virol. 2014;58:95-8.

8. Racey PA, Hutson AM, Lina PHC. Bat rabies, public health and European Bat conservation. Zoonoses Public Hlth. 2012;60:58-68.

9. Drexler JF, Corman VM, Wegner T, Tateno AF, Zerbinati RM, Gloza-Rausch F, et al. Bats host major mammalian Paramyxoviruses. Emerg Infect Dis. 2012;17:449-56.

10. Müller T, Johnson N, Freuling CM, Fooks AR, Selhorst T, Vos A. Epidemiology of bat rabies in Germany. Arch Virol. 2007;152:273-88.

11. Gloza-Rausch F, Ipsen A, Seebens A, Göttsche M, Panning M, Drexler JF, et al. Detection and prevalence patterns of group I Coronaviruses in bats, Northern Germany. Emerg Infect Dis. 2008;14:626-31.

12. Uhrin M, Kanuch P, Kristofik J, Paule L. Phenotypic plasticity in the greater mouse-eared bat in extremely different roost conditions. Acta Theriol. 2010;55:153-64.

13. Mihalca AD, Dumitrache MO, Magdaș C, Gherman CM, Domşa C, Mircean V, et al. Synopsis of the hard ticks (Acari: Ixodidae) of Romania with update on host associations and geographical distribution. Exp Appl Acarol. 2012;58:183-206.

14. Rupp D, Zahn A, Ludwig P. Actual records of bat ectoparasites in Bavaria (Germany). Spixiana. 2004;27:185-90.

15. Lourenco SI, Palmeirim JM. Can mite parasitism affect the condition of bat hosts? Implications for the social structure of colonial bats. J Zool. 2007:273:161-8.

16. Zahn A, Rupp D. Ectoparasite load in European vespertilionid bats. J Zool. 2004;262:383-91.

17. Jaunbauere G, Salmane I, Spungis V. Occurrence of bat ectoparasites in Latvia. Latv Entomol. 2008;45:38-42.

18. ChiroTEC. [http://www.chirotec.de/cms/index.php]. Accessed May 2014.

19. Dietz M, Simon M, Hessen-Forst FENA Naturschutz. Artgutachten 2011 Bundesstichprobenmonitoring 2011 von Fledermausarten (Chiroptera) in Hessen Großes Mausohr (Myotis myotis). Gießen; 2013.

20. Bush O, Lafferty AD, Lotz JM, Shostak AW. Parasitology meets ecology on his own terms: Margolis et al. revisited. J Parasitol. 1997;83:575-83.

21. Shannon CE, Weaver W. The mathematical theory of communication. Vienna: University of Illinois Press; 1949.

22. Ivanova NV. deWaard J, Hebert PDN: An inexpensive, automation-friendly protocol for recovering high quality DNA. Mol EcolNotes. 2006;6:998-1002.

23. Altschul SF, Gish W, Miller W, Myers EW. LipmanDJ: Basiclocal alignment search tool. J Mol Biol. 1990;215:403-10.

24. Genov T, Stoykova-Hajinikolova R, Meszaros F. Molinostrongylus spp. (Nematoda: Molineidae) from bats in Bulgaria, with a review of European species. Parasit Hung. 1992;25:53-68.

25. Brinck-Lindroth G, Smit F. GAM: The fleas (Siphonaptera) of Fennoscandia and Denmark. Boston: Brill Leiden; 2007.

26. Tian ZZ, Jin DC. Study on the genus Macronyssus (Acari: Macronyssidae) with description of a new species, redescription of a known species from 
the genus Myotis (Chiroptera: Vespertilionidae) and a key to the species in China. Int J Acarol. 2012;38:179-90.

27. Pocora I, Sevcik M, Uhrin M, Bashta AT, Pocora V. Morphometric notes and nymphal stages description of mite species from the Spinturnix myoti group (Mesostigmata: Spinturnicidae) from Romania and Ukraine. Int J Acarol. 2013;39:153-9.

28. Friedrich-Loeffler-Institut Bundesforschungsinstitut für Tiergesundheit. Amtliche Methodensammlung Januar 2014. Greifswald - Insel Riems; 2014.

29. Berthier $P$, Excoffier $L$, Ruedi $M$. Recurrent replacement of mtDNA and cryptic hybridization between two sibling bat species Myotis myotis and Myotis blythii. Proc R Soc B. 2006:42:143-8.

30. Bruyndonckx N, Dubey S, Ruedi M, Christe P. Molecular cophylogenetic relationships between European bats and their ectoparasitic mites (Acari, Spinturnicidae). Mol Phylogenet Evol. 2009;51:227-37.

31. Danko S, Kristin A, Kristofik J. Myotis alcathoe in eastern Slovakia: occurrence, diet, ectoparasites and notes on its identification in the field. Vespertilio. 2010;13-14:77-91.

32. Kristofik J, Danko S. Arthropod ectoparasites (Acarina, Heteroptera, Diptera, Siphonaptera) of bats in Slovakia. Vespertilio. 2012;16:167-98.

33. Hornok S, Kontschan J, Kovats D, Kovacs R, Angyal D, Görföl T, et al. Bat ticks revisited: Ixodes ariadnae sp. nov. and allopatric genotypes of I. vespertilionis in caves of Hungary. Parasite Vector. 2014;7:1-9.

34. Sevcik M, Benda P, Lucan RK. Diptera Pupipara from bats of two large eastern Mediterranean islands, Crete and Cyprus. Turk J Zool. 2013;37:31-37.

35. Lanza B: I parassiti dei pipistrelli (Mammalia, Chiroptera) della fauna italiana. Turin: Museo Regionale di Scienze Naturali; 1999.

36. Meszaros F. An examination of native bats for parasitic nematodes. Allattani Kozl. 1971:58:78-86.

37. Walter G, Kock D. Verbreitung und wirtsarten der fledermaus-flöhe Deutschlands. Senckenb Biol. 1994;74:103-25.

38. Baker AS, Craven J. Checklist of the mites (Arachnida: Acari) associated with bats (Mammalia: Chiroptera) in the British Isles. Syst Appl Acarol Spec Publ. 2003;14:1-20.

39. Deunff J, Walter G, Bellido A, Volleth M. Description of a cryptic species Spinturnix bechsteini n. sp. (Acari, Mesostigmata, Spinturnicidae), parasite of Myotis bechsteinii (Kuhl, 1817) (Chiroptera, Vespertilionidae) by using ecoethology of host bats and statistical methods. J Med Entomol. 2004:41:826-32.

40. Siuda K, Stanko M, Piksa K, Gorz A. Ticks (Acari: Ixodida) parasitizing bats in Poland and Slovakia. Wiad Parazytol. 2009;55:39-45.

41. Dekeukeleire D. Local host-parasite dynamics and phylogeography of the bat fly Basilia nana. Master thesis: University of Gent, Research Group Evolutionary Morphology of Vertebrates; 2012

42. Haitlinger R, Piksa K. First record of Spinturnix bechsteini (Acari: Mesostigmata: Spinturnicidae) from Poland with remarks on the diagnostic value of some characters. Ann Parasitol. 2012;58:15-8.

43. Sevcik M, Benda P, Lucan RK. New records of ticks (Acari: Ixodidae) parasitizing on bats in Slovakia. Vespertilio. 2010;13-14:139-47.

44. Botella P, Esteban JG. Histopathology of the stomach lesion caused by Physaloptera brevivaginata (Nematoda: Physalopteridae) in bats in Spain. Folia Parasitol. 1995:42:143-8.

45. Esteban JG, Botella P, Toledo R, Oltra-Ferrero JL. Helminthfauna of bats in Spain. IV. Parasites of Rhinolophus ferrumequinum (Schreber, 1774) (Chiroptera: Rhinolophidae). Res Rev Parasitol. 1999;59:57-68.

46. Lindecke O, Scheffler I. Zur Ektoparasitenfauna der Fledermäuse in SachsenAnhalt. Hercynia NF. 2011:44:241-51.

47. Esteban JG, Mas-Coma S, Oltra-Ferrero JL, Botella P. Aonchotheca moraveci sp. n. (Nematoda: Trichuridae), a new nematode from the long-fingered bat, Myotis capaccinii, in Spain. Folia Parasitol. 1991;38:319-26.

48. Radovsky FJ. The Macronyssidae and Laelapidae (Acarina: Mesostigmata) parasitic on Bats. California: University of California Press; 1967

49. Zdzietowiecki K. Helminths of bats in Poland. I. Cestodes and trematodes of the family Plagiorchiidae. Acta Parasit Pol. 1970;17:175-88

50. Orlova MV, Zapart A. Interactions of ectoparasites in cohabitating colonies of pond bats Myotis dasycneme (Boie, 1825) and species of genus Pipistrellus from northern Poland. Ann Parasitol. 2012;58:211-5.

51. Till WM. Evans O: The genus Steatonyssuskolenati (Acari: Mesostigmata). Bull Br Mus (Nat Hist) Zool. 1964;11:511-82.

52. Lucan RK. Relationships between the parasitic mite Spinturnix andegavinus (Acari: Spinturnicidae) and its bat host, Myotis daubentonii (Chiroptera: Vespertilionidae): seasonal, sex-and age-related variation in infestation and possible impact of the parasite on the host condition and roosting behaviour. Folia Parasit. 2006:53:147-52.

53. Haitlinger R, Lupicki D. Arthropods (Acari, Siphonaptera, Heteroptera, Psocoptera) associated with Nyctalus noctula (Schreber, 1774) (Chiroptera: Vespertilionidae) in Southern Poland. Wiad Parazytol. 2008;54:123-30.

54. Piksa K, Skwarek M, Siuda K. Argasid and Spinturnicid mite load on swarming bats in the Tatra Mountains, Poland. Folia Parasit. 2011;58:322-5.

55. Kochseder G. Untersuchungen an Hymenolepis grisea (VAN BENEDEN, 1873) (Hymenolepidae) aus Fledermäusen aus der Steiermark. Z Parasitenkunde. 1969:32:43-7.

56. Kristofik J, Piksa K, Sachanowic K. Two spinturnicid mites new to the fauna of Poland (Acari: Spinturnicidae). P J E. 2012;81:101-6.

57. Murai E. Cestodes of bats from Hungary. Parasit Hung. 1976;9:41-62.

58. Brglez J, Bidovec A. Three species of Trichostrongylidae, Leiper 1912, in some wild animals in Slovenia. Zbornik Veterinarstvo. 1987:24:167-72.

59. Hennecke M. Die Fledermäuse Hessens. Remshalden-Buoch: Publisher Manfred Hennecke; 1994.

60. Shimalov W, Demyanchik MG, Demyanchik VT. A study on the helminth fauna of the bats (Mammalia, Chiroptera: Vespertilionidae) in Belarus. Parasitol Res. 2002;88:1011.

61. Schmölzer K. Catalogus Faunae Austriae. Teil IX f. Vienna: Verlag der Österreichischen Akademie der Wissenschaften; 1995.

62. Bogdanowiczi W, Van den Bussche RA, Gajewska M, Postawa T, Harutyunyan MA. Ancient and contemporary DNA sheds light on the history of mouse-eared bats in Europe and the Caucasus. Acta Chiropterol. 2009;11:289-305.

63. Ruedi M, Mayer F. Molecular systematics of bats of the genus Myotis (Vespertilionidae) suggests deterministic ecomorphological Convergences. Mol Phylogent Evol. 2001;21:436-48.

64. Bruyndonckx N, Biollaz F, Dubey S, Goudet J, Christe P. Mites as biological tags of their hosts. Mol Ecol. 2010;19:2270-778.

65. Barus V. Daniel M. The occurrence of some helminth species in birds and mammals from Yugoslavia. Folia Parasit. 1972;19:111-2.

66. Kulzer E. Handbuch der Zoologie. Chiroptera. Volume 3. Berlin: Walter de Gruyter publisher; 2005

67. Christe $P$, Arlettaz $R$, Vogel P. Variation in intensity of parasitic mite (Spinturnix myoti) in relation to the reproductive cycle and immunocompetence of its bat host (Myotis myotis). Ecol Lett. 2000;3:207-12.

68. Christe P, Glaizot O, Evanno G, Bruyndonckx N, Devevey G, Yannic G, et al. Host sex and ectoparasites choice: preference for, and higher survival on female hosts. J Anim Ecol. 2007;76:703-10.

69. Zander CD. Parasit-Wirt-Beziehungen. Berlin, Heidelberg: Springer; 1998.

70. Giorgi MS, Arlettaz R, Christe P, Vogel P. The energetic grooming costs imposed by a parasitic mite (Spinturnix myoti) upon its bat host (Myotis myotis). Proc R Soc B. 2001;268:2070-5.

71. Christe P, Giorgi MS, Vogel P, Arlettaz R. Differential species-specific ectoparasitic mite intensities in two intimately coexisting sibling bat species: resource-mediated host attractiveness or parasite specialization? J Anim Ecol. 2003;72:866-72.

72. Traversa D. Fleas infesting pets in the era of emerging extra-intestinal nematodes. Parasite Vector. 2013:6:1-15.

73. Denegri GM. Review of oribatid mites as intermediate hosts of tapeworms of the Anoplocephalidae. Exp Appl Acarol. 1993;17:567-80.

74. Steinmann P, Cringoli G, Bruschi F, Matthys B, Lohourignon LK, Castagna B, et al. FLOTAC for the diagnosis of Hymenolepis spp. infection: proof-of-concept and comparing diagnostic accuracy with other methods. Parasitol Res. 2012;111:749-54.

75. Orlova MV. Invasion of specific ectoparasites of Siberian-Far Eastern bat species to the Urals. Rus J Biol Invasion. 2014;5:29-31.

76. Frank R, Münster J, Schulze J, Liston A, Klimpel S. Macroparasites of Microchiroptera: bat ectoparasites of Central and South America. In: Bats (Chiroptera) as Vectors of Diseases and Parasites. Volume 5. Edited by Mehlhorn H and Klimpel S. Heidelberg: Springer; 2014: 87-130.

77. Gunnell GF, Simmons NB. Fossil evidence and the origin of bats. J Mamm Evol. 2005:12:209-46

78. Simmons NB. An Eocene big bang for bats. Science. 2005;307:527-8.

79. Poinar G, Brown A. The first fossil streblid bat fly, Enischnomyia stegosoma n. g., n. sp. (Diptera: Hippoboscoidea: Streblidae). Syst Parasitol. 2012;81:79-86. 